\title{
Liturgijska duhovnost bl. Ivana Merza
}

\author{
Franjo Podgorelec*, Ivan Crnković**
}

»Ivan Merz je u školi bogoslužja, koje je vrelo i vrhunac života Crkve (usp. $S C, 10)$, stasao do punine kršćanske zrelosti i postao je jedan od promicatelja bogoslužne obnove u svojoj domovini. Sudjelujući u misi te hraneći se tijelom Kristovim i riječju Božjom, nalazio je poticaj da bude apostol mladeži« (Ivan Pavao II., 2003, 542).

\begin{abstract}
Sažetak
Ivan Merz neosporno je jedan od važnih protagonista liturgijskog pokreta osobito među hrvatskom mladeži. Njegov je glavni doprinos egzistencijalne naravi: svojim životom postao je autentični model na koji način ono što se slavi u liturgiji može i treba formirati kršćaninovu svakodnevicu.

U radu će se analizirati njegovi spisi, iskustvo kao i brojna svjedočanstva o njemu. Povijesno-opisnom metodom predstaviti će se neki prijepori oko liturgijske duhovnosti onoga vremena.

Ključne riječi: liturgijska duhovnost, izvanliturgijska pobožnost, Katolička akcija, primat kontemplacije, liturgijski pokret, jedinstvo života
\end{abstract}

\section{Uvod}

Naslov članka jasno sugerira da će se raspravljati o odnosu liturgije i duhovnog života. Te su dvije stvarnosti, kroz postridentsko razdoblje, bile odijeljene, a liturgijski je pokret nanovo nastojao vratiti liturgiju kao izvor kršćaninova duhovnog života, čiju je ideju usvojio i Drugi vatikanski koncil. Ivan Merz, pristaša liturgijskog pokreta, tu je ideju osobno živio i promovirao među mladima s kojima je surađivao u sklopu Katoličke akcije. Tu njegovu crtu istakao je i sv. papa Ivana Pavao II. u Misi beatifikacije, a papa Benedikt XVI. u postsinodalnoj pobudnici navodi ga među svjedocima autentičnog duhovnog života temeljenog na euharistiji (SAC 94). Ovim se člankom blaženik želi predstaviti kao autentični model liturgijske duhovnosti.

* Doc. dr. sc. Franjo Podgorelec, Katolički bogoslovni fakultet Sveučilišta u Zagrebu. Adresa: Vlaška 38, 10000 Zagreb, Hrvatska. E-pošta: franjo.podgorelec@gmail.com

** Ivan Crnković, ofm, dipl. teol., Katolički bogoslovni fakultet Sveučilišta u Zagrebu. Adresa: Vlaška 38, 10000 Zagreb, Hrvatska. E-pošta: ivan.crnkovic11@gmail.com 
U prvom poglavlju liturgija se predstavlja kao eklezijalna duhovnost te se razlaže na koji je način Ivan realizirao aktivnu i svjesno sudioništvo u liturgiji. Potom se obrazlaže da primat liturgijskog života kod njega nije vodio u isključivost ili zanemarivanje izvanliturgijske pobožnosti i individualne molitve. Na kraju se naglašava potreba povezanosti između liturgije i vjernikove svakodnevice te njegova društvena angažmana. Samo u uzglobljenosti tih triju elemenata, prema Merzu, može se razvijati istinska liturgijska duhovnost.

\section{1. »Liturgija je prvo, i to nužno vrelo iz kojega vjernici trebaju crpsti pravi kršćanski duh«(SC 14)}

»Oduševljavao nas je za liturgiju i moljenje sv. mise iz misala«(Jäger, 1938, 302).

Poznavatelji Merzova života i spisa jasno potvrđuju da je on autentičan model liturgijske duhovnosti (Prétot, 2013, 379), ako ono što slavimo treba oblikovati našu misao i djelovanje, sukladno sljedećoj definiciji: »Liturgijska duhovnost je kršćaninov stav na kojemu temelji svoj život — čitav svoj život svjesno življen — na autentičnoj liturgijskoj praksi, na način da ona postane 'culmen et fons' sve njegove djelatnosti (usp. SC 10), da bi, u konačnici, 'mysterium pashale vivendo exprimatur' " (Neunheuser, 2001a, 1915). Za njega »liturgija je izražaj duše Crkve (Merz, 2014, 387), ona je eklezijalna duhovnost i kao takva, ona treba biti primarno sredstvo posvećenja.

\subsection{Liturgija kao eklezijalna duhovnost}

»Liturgija je izražaj duše Crkve«(Merz, 2014, 387).

Liturgija i Crkva središnja su preokupacija našeg blaženika, dotle da je od njih učinio »jedini smisao svoga kratkog života« (Žanko, 1928, 250). Te dvije stvarnosti u njegovu su nauku neodvojive i jedna na drugu upućene. Kao zdušni promotor liturgijskog pokreta, on je u potpunosti usvojio jednu od njegovih nosivih eklezioloških ideja, da je Crkva, naime, ponajprije Otajstvo. To znači da bitno nije ono vidljivo, vanjska organizacija, nego nevidljiva stvarnost, Krist, pred kojim Crkva u liturgiji biva u poklonstvenom stavu (Neunheuser, 2001b, 1285). Merzovi suvremenici svjedoče da je on Crkvu doživljavao poglavito u »njezinu najbitnijem, najunutrašnjijem, najvitalnijem, čistom, svrhunaravnom, mističnom pojmu « (Žanko, 1928, 250), ona je za njega »veleban odraz samog neizmjernog Krista « (Merz, 2011, 178).

Proučavajući povijest kršćanstva, blaženik uočava mnogovrsne i šarolike manifestacije duhovnog života u Crkvi koje imaju svoj izražaj u različitosti redova, karizmi i djelatnosti. Jedna je od takvih suvremenih manifestacija i Katolička akcija koja teži za rekristijanizacijom društva. On, ipak, tim manifestacijama pridaje tek „akcidentalnu“ važnost. Za njega je „bitno“ i ,supstancijalno“ ono što je u osnovi svim tim povijesnim manifestacijama i nepromjenljivo, a to je duhovni život: »odnos duša spram Boga i djelatnost koju Milost Božja obavlja u njihovim dušama « (Merz, 2011, 173). Duhovni život uvijek je isti i treba biti primarna briga 
svakog kršćanina, i samo će njegovim primatom čovjekova akcija biti uspješna (Merz, 2011, 174).

Crkva kao zajednica svoj duhovni život živi i izražava u liturgiji koja je »službena molitva Crkve, službena molitva Zaručnice Kristove, razgovor između Zaručnice i božanskog Zaručnika« (Merz, 2011, 174). Nije samo Crkva kao cjelina Kristova Zaručnica, nego je to i svaka pojedina duša. Svaki kršćanin pozvan je stoga da se pridruži tomu velebnomu dijalogu koji se događa u liturgiji, što uključuje da je što »temeljitije upoznamo i da se s njom što više okoristimo« (Merz, 2011, 174). Po liturgijskoj molitvi naša »osobna molitva, koja je jednostrana (jer je također uvjetovana povijesnim miljeom i stupnjem obrazovanja onoga tko moli) postaje socijalna i univerzalna « (Merz, 2011, 179). Povezanost između Crkve i liturgije on i pneumatološki utemeljuje. Smatra da je Duh Sveti duša Crkve te da on nadahnjuje i sam njezin liturgijski život (Merz, 2011, 132).

Upravo stoga što liturgijski život uređuje Crkva koja posjeduje puninu Duha, i k tomu višestoljetno iskustvo, ona preko liturgije nudi eklezijalnu pedagogiju za osobni duhovni život. Kroz liturgiju Crkva nudi teološki bogat i ispravan sadržaj (lex orandi lex credendi), koji vodi računa o cjelovitom Kristovom otajstvu i kao takva korektiv je pučkoj pobožnosti kod koje »neodređeni osjećaji [...] donose sa sobom mnogo puta različite zablude praznovjerja i krivih vjerskih nazora « (Merz, 2011, 281). Zato naša osobna duhovnost »treba živjeti s Crkvom« (Merz, 2011, 281), tj. voditi računa o formama molitvena i duhovna života koje ona preporuča. Bio je to za njega jedan od temeljnih oblika sentire cum Ecclesiae, kao što svjedoči teolog koji ga je osobno poznavao (Hausherr). Za rimski misal, koji je tada preveden na hrvatski jezik, reče da je »najpedagoškije djelo što ga imamo: on je pedagogija 'par excellence' " (Merz, 2011, 132). Identično tvrdi i za liturgiju u cjelini (Merz, 2011, 132). On je u suradnji s Kniewaldom »prvi uveo hrvatsku katoličku mladež u život s Crkvom po liturgiji« (Škarica, 1997, 267).

\subsection{Actuosa participatio}

U postridentskom razdoblju glavni izvor duhovnosti kršćanskog puka bila je pučka pobožnost te individualna molitva. Liturgijski pokret nastojao je iznova vratiti liturgiju kao glavni izvor duhovnog života.

Dugo je liturgija bila promatrana kao opus sacerdotis, što svećenik, uz nazočnost naroda (praesente populo), ${ }^{1}$ obavlja sam u korist sviju. Postojale su »gotovo dvije paralelne liturgije« (Benedikt XVI., 2013.), jednu je obavljao svećenik iz misala, a narod je bio pasivno nazočan moleći svoje privatne molitve. U težnji da se nadiđe dotična dihotomija, isticala se potreba da svi imaju učešća u bogatstvu koje liturgija sadržava i pruža. Stoga su poduzimani koraci da vjernici

1 Dok je svećenik u misnoj žrtvi prije izgovarao: qui tibi offerunt hoc sacrificium laudis („,koji ti prinose“), od 8. stoljeća nadodaje: vel pro quibus tibi offerimus (,za koje ti prinosimo“). Nauštrb općeg svećeništva vjernika naglašava se ministerijalno (Vauchez, 2006, 13). 
imaju "puno, svjesno i aktivno učešće u liturgijskim slavljima« (SC 14; usp. također 48; 52-63), što je izraženo sintagmom actuosa participatio.

Blaženik se zdušno zalagao da liturgija ponovno postane mjesto susreta i dijaloga s Bogom i formacije zrelih kršćana. Stoga je najvažniji zadatak liturgiju »upoznati što temeljitije « (Merz, 2011, 174). Potiče da se za vrijeme mise ne obavljaju privatne pobožnosti, nego da se nastoji »zajedno sa svećenikom moliti« (Merz, 2011, 281). Liturgiju, nadalje, treba slaviti »svjesno« (Merz, 2011, 282) što će omogućiti vjerniku da bude »sudionikom velikih milosti« (Merz, 2011, 282).

Posebno je važno to što se trudio povezati osobnu meditaciju i liturgiju. Misal kojim pažljivo prati sv. misu postaje ujedno i njegov »najljepši molitvenik« (Merz, 2011, 281), na temelju kojeg obavlja ponekad i osobnu meditaciju. Franjo Šeper svjedoči kako su za vrijeme povratka s jednog predavanja došli na razgovor o Malom oficiju Bl. Djevice Marije. Tom prigodom mu je protumačio antifone s Večernje molitve, koje nigdje nije čitao, stoga je zaključio da je to sigurno »plod njegove meditacije « (Šeper, 1970). On i drugima preporuča da kombiniraju »liturgijsku molitvu s običnom meditacijom « (Merz, 2011, 177). Možda najbolje tu povezanost liturgije, kao objektivne molitve Crkve, i osobne meditacije, kao subjektivne molitve, potvrđuje sljedeće svjedočanstvo:

One smo večeri, sjećam se dobro, razgovarali o razmatranju. Ivo nam je tumačio, što je razmatranje i kako ga možemo svako jutro zgodno obaviti. Spojiti ga sa sv. misom, s misalom! Uzmite koji tekst sv. mise i razmatrajte ga, primijenite uvijek na sebe i odlučite provesti u duši spoznanu istinu (Jäger, 1938, 301).

Bilo je onih koji su davali objekcije na takva njegova inzistiranja, smatrajući da svoju aktivnu i afektivnu dimenziju duhovnog života mogu bolje doživjeti i izraziti u izvanliturgijskoj pobožnosti, nego li u liturgiji samoj. Merz na to odgovara: »Ponajprije, to što ne uspijevaš izlijevati svu dušu kod liturgijskih molitava, kao kod one svoje posebne, individualne pobožnosti, jest zato jer se nisi dovoljno zadubila u ljepotu liturgijskih molitava (Merz, 2011, 281282). Budući da to nije moguće za vrijeme mise, on preporuča »češće za svoga slobodnoga vremena izvan sv. mise čitati liturgijske molitve, o njima razmišljati i nastojati što dublje ući u njihov smisao « (Merz, 2011, 282). Ne zadovoljava se, stoga, pukom nazočnošću na misi kao moralnoj obvezi, nego se liturgija »mora proživljavati« (Merz, 2011, 291). Ponekad se može dogoditi »da nas ljepota neke molitve tako osvoji da u nju zaronimo i zastanemo« (Merz, 2011, 282).

Svjesno sudjelovanje na liturgiji, ujedno je, prema njemu, najbolja priprava i zahvala za sv. Pričest (Merz, 2011, 282-291), koja je za njega »vrhunac cjelokupne liturgije« (Merz, 2011, 178) kao i vjerskog života. Sva bi čovjekova aktivnost trebala biti kristocentrična, što znači usmjerena prema tomu činu u kojem se sjedinjujemo s Kristom (Merz, 2011, 178). 


\section{2. »Duhovni se život ipak ne sastoji samo od sudjelovanja u svetoj liturgiji (SC 12)}

»Uz liturgijsku pobožnost dopuštena je i osobna, posebna, individualna«

(Merz, 2011, 292).

\subsection{Objektivna i subjektivna duhovnost}

U sklopu liturgijskog pokreta vodila se i važna rasprava o odnosu liturgije prema drugim oblicima i formama duhovnog života, koji su bili dominantni u postridentskom razdoblju: pučkoj pobožnosti, individualnoj molitvi, askezi i sl. Nerijetko su neliturgijske forme simplicistički okarakterizirane kao relikt postridentske individualističke duhovnosti. Benediktinac M. Festugière u svojem članku La liturgie catholique („Katolička liturgija“) objavljenom 1913. godine, u želji da afirmira i obrani liturgiju suprotstavio je „objektivnu“ duhovnost, koja proizlazi iz otajstava Crkve (a slavi se u liturgiji), do tada raširenoj „subjektivnoj“ individualnoj i psihološkoj duhovnosti (individualna molitva, pučka pobožnost, askeza). Izravno je pritom prozvao ignacijansku duhovnost.

Isusovac J. Navatel, braneći korisnost osobne molitve i askeze, sukladno smjernicama njegova utemeljitelja, upozorio je i na pretjerivanja izvjesnog „liturgizma“, koji prema njemu vodi u stanoviti „semikvijetizam“. To znači da liturgija premalo angažira čovjeka i njegovu suradnju (Castellano, 2003, 214-219). Tu poziciju zastupali su i američki karmelićani u časopisu Spiritual Life (osobito 1959. godište). Posebnu pozornost privukao je članak bračnog para Jacquesa i Raïse Maritain Liturgy and Contemplation („Liturgija i kontemplacija“), u kojem, između ostalog, ističu da je liturgija, doduše, sveta stvar, ali kontemplacija teži višemu cilju (Castellano, 2003, 218).

Činjenica je da su teolozi duhovnosti najduže »nastavili ignorirati liturgiju « (Castellano, 2003, 218). Tako i naš teolog duhovnosti na Antonianumu u Rimu i Merzov suvremenik, sluga Božji Aleksa Benigar (1893.-1988.), podosta se kritički osvrće na kolektivističku tendenciju izvjesnog liturgizma koji obezvrjeđuje osobnu molitvu. Ipak na koncu iznosi uravnotežen stav: »Liturgijska molitva, koja se ne hrani i pripravlja osobnom molitvom, postaje sve više ispunjavanje dužnosti ili neka predstava. Razmatranje koje se ne izlijeva u zajedničku molitvu i svetu žrtvu, postaje izolirani čin religije « (Benigar, 2014, 149-150). ${ }^{2}$ Nekako u isto vrijeme kad i Benigar, ${ }^{3}$ i Albino Luciani, budući papa Ivan Pavao I., upozorio je pred kraj Koncila na »opasnost pretjerivanja«izvjesnog »panliturgizma« (Luciani, 1980, 335). ${ }^{4}$

2 Zanimljivo da Benigar, u istom kontekstu, brani privatnu i tihu misu, a Merz ističe da je ideal pjevana misa (Merz, 2011, 135).

3 Sam svjedoči da je komentar na Matejevo evanđelje pisao dok je bio duhovnik studenata u Kolegiju sv. Antuna u Rimu (1955.-1965.) (Benigar, 2014, 15).

4 Duhovne vježbe držao je župnicima Venetske biskupije od 1 do 15 . siječnja 1965. godine. 


\subsection{Merzova integracija izvanliturgijske duhovnosti}

Merz je bio revan proučavatelj dokumenata crkvenog učiteljstva i njihov promicatelj, kako u osobnom životu, tako i u poučavanju drugih (Šeper, 1070). Zato on nikada nije upao u dihotomiju između liturgijske i izvanliturgijske duhovnosti. Njegova misao i praksa išli su u tri pravca: isticao je primat liturgije; nastojao da sama liturgija postane subjektivno proživljavana kao i predmet same osobne meditacije; i na koncu, revno je prakticirao te promovirao i izvanliturgijske pobožnosti.

Uzglobljenost tih triju pravaca uočljiva je već u samoj strukturi njegova dnevnog reda koji je provodio. Kada je, naime, 1925. godine, Dragutin Kniewald proveo anketu među mladima u Hrvatskoj o vjerskom i moralnom životu, priređujući izdanje molitvenika, blaženik je u toj anketi dao sljedeće odgovore: »Što sam radio pod sv. misom? Molio sv. misu. Što molim ujutro i uvečer? Ujutro: razmatram 3/4 sata. Navečer: krunica, ispitivanje savjesti, pripravim materijal za razmatranje sljedećeg dana« (Nagy, 1971, 269). Vidljiva je prirodna povezanost između liturgije, individualne meditacije i pučke pobožnosti. Kada veli da je molio sv. misu, prije svega misli na to da ju je redovito pratio iz svojeg latinsko-francuskog misala i zajedno sa svećenikom u sebi molio misne molitve.

Liturgija za Merza ima primat jer se usredotočuje na Kristovo otajstvo, a ne toliko na subjektivno stanje osobe. Tijekom liturgijske godine uvodi nas u cjeloviti misterij Krista, a ne tek u jedno od otajstava njegova života. Svojim molitvama teološki nas ispravno uvodi u misterij koji se slavi te našoj individualnoj i privatnoj molitvi daje socijalnu i univerzalnu dimenziju (Merz, 2011, 132), izraženo osobito u stvarnosti općinstva svetih (Merz, 2011, 132-178).

Sukladno toj ideji primata, nastojao je da i osobna molitva bude povezana s liturgijom, da tema meditacije budu liturgijska čitanja, kao i liturgijske molitve, antifone i sl. Jedan od savjeta koje preporuča za obnovu po liturgiji glasi: »Razmatraj svaki dan na temelju misala « (Merz, 2011, 176). Štoviše, inzistirao je da sama liturgija postane sve više meditativna, da je osobno proživljavamo, da svjesno i sabrano pratimo molitve, ne isključujući ni dublje unutarnje iskustvo kao što je sam imao (Merz, 2014, 159).

No, on je također bio upoznat s uravnoteženim stavovima crkvenog učiteljstva da je »uz liturgijsku pobožnost dopuštena i osobna, posebna, individualna« (Merz, 2011, 292).

Za vrijeme boravka na ratištu Merza je u razmatranje uputio jedan franjevac kojeg je posjećivao u Bolzanu u razdobljima ratnih zatišja. Izjavio je kako ga je dotični franjevac uputio u »tajne sistematske meditacije « (Nagy, 1971, 141). Za vrijeme duhovnih vježbi 1923. godine na pet araka Ivan Merz je sastavio izvadak iz rasprave isusovca o. Roothana o razmatranju, koji mu je služio kao početni priručnik (Vrbanek, 1943, 195). Pozivajući se na nauk sv. Terezije Avilske o stupnjevima kontemplacije, njegov ispovjednik smatra da je imao više stupnjeva kontemplativnog iskustva (Vrbanek, 1943, 197).

Prema svjedočanstvima, blaženik je »razmatrao svaki dan« (Gračanin, 1993) te uvodio i druge u meditaciju (Stanković, 1938, 285). Đuro Gračanin svjedoči da je na putu vlakom u Rim rado razgovarao, »ali i često prekidao razgovor po čitav sat, dva te molio i razmatrao« (Gračanin, 1993). 
Osim razmatranja Merz je u svojem dnevnom životu prakticirao i druge oblike pobožnosti i molitve koje je Crkva preporučala. Dnevno je molio i razmatrao krunicu, koja će mu po povratku s hodočašća u Lourdes nakon euharistije biti „drugi najbolji prijatelj« (Merz, 2014, 425). Volio je obavljati pohode Svetootajstvu (Nagy, 2005, 44), a na galeriji bazilike Srca Isusova u Zagrebu često je obavljao križni put (Vrbanek, 1943, 203). Merz je također gajio posebnu pobožnost prema Presvetomu Srcu Isusovu, kojemu je upravljao svoje molitve za obraćenje svojih roditelja (Merz, 2014, 364), a spominje to otajstvo i u svojoj duhovnoj oporuci (Merz, 1993, 190-191).

Kao sintezu i zaključak te točke možemo navesti činjenicu da je u njegovu dnevnom redu »točno predviđena sv. misa, i sv. pričest, razmatranje, krunica, križni put, liturgijski tekstovi, ispitivanje savjesti, euharistijski pohodi itd. Nikad ne riskira mješavinu autentične molitve s nesređenim emocijama, a čvrsto zagovara objektivnu molitvu Crkve namjesto subjektivne, naročito kad se radi o misi« (Žanko, 1938, 270-271).

\section{Mysterium paschale vivendo exprimatur (IO 6)}

»A mi, kada zavirimo pomoću presv. liturgije u unutarnji život Božji, tad iz njega crpimo cijelu metodu akcije» (Merz, 2011, 176).

Budući da duhovnost naglašava asimilacijski čin vjere (fides qua), valja liturgijski život u Ivana Merza predstaviti na način da se pokaže kako on ima pozitivne posljedice na njegov svakodnevni život. Ukoliko bi liturgija ostala bez povezanosti s ostalim čovjekovim djelatnostima, s njegovom konkretnom svakodnevicom, onda bi promašila svoju svrhu. Stoga je »potrebno da se euharistija, kao izvor i vrhunac života i poslanja Crkve, pretoči u duhovnost « (SAC 77). U konačnici, to je bio središnji cilj liturgijskog pokreta, osobito koncilske liturgijske reforme (Häring, 1966, 15-16). Neki teolozi upozoravaju da se u novije vrijeme iznova uočava tendencija odvajanja liturgije od svakodnevnog života i zalaganja za čovjeka (Faggioli, 2015, 677), na što je upozorio i sadašnji papa u svojoj programatskoj enciklici: »Kod nekih ljudi primjećujemo razmetljivu brigu za bogoslužje, učenje i ugled Crkve, ali ne pokazuju nikakvu brigu za stvarno ucjepljivanje evanđelja u Božji narod i u konkretne potrebe sadašnjeg trenutka« (EG 95).

Blaženik ne sumnja da liturgija, ako je svjesno i aktivno proživljavana, ima potencijal da formira autentične apostole i graditelje bolje Crkve i društva: »Preporučujemo, dakle, svakomu, a osobito članovima našega pokreta, da tu knjigu (misal) nabave i prema njoj urede svoj život. Uvjereni smo da će ona odgojiti niz solidnih, požrtvovnih, katoličkih radnika« (Merz, 2011, 134). Opisujući, u svojoj doktorskoj disertaciji, utjecaj liturgije na francuske pisce, Merz ističe njezinu „konverzijsku snagu“ (Ribić, 2013, 163).

Važno je stoga u jednoj zdravoj liturgijskoj duhovnosti iznova naglasiti jedinstvo između kontemplativne i aktivne dimenzije života. To jedinstvo života snažno je preporučio Koncil na više mjesta. Koncilski otci smatraju da vjernici 
laici mogu rasti u sjedinjenju s Kristom ne samo po liturgiji i ostalim sredstvima posvećenja, nego također i kroz svjetovne poslove ako ih vrše po Božjoj volji (AA 4). To jedinstvo temeljeno je u svijesti kršćanskog identiteta, kao i na kršćanskoj savjesti koja je jedna i nepodijeljena, neovisno o tome gdje se čovjek nalazio ili čime se bavio. Ivan Merz bio je »uvijek isti...; kakav u Crkvi, na ulici, takav i kod kuće: uvijek gospodar samoga sebe, dobar kao nevino dijete, prostodušan « (Jäger, 1938, 303). Biskup hvarski msgr. Miho Pušić upoznao je Merza 1927., kad se nalazio u Hvaru na liječenju. Uočio je kod blaženika istodobno veliku pobožnost i veliki angažman oko rada s mladima da ih pridobije za Katoličku akciju i Božju stvar: »On je u sebi ostvario sintezu unutarnjeg intenzivnog duhovnog života i apostolskog djelovanja, a to je sigurno jedini pravi put i za današnju katoličku mladež« (Pušić, 1966, 227). Kao takav, svima je bio svjetionik i poticaj za »dvije različite stvari, koje ipak idu skupa: po vanjskoj aktivnosti među ljudima i po unutarnjoj aktivnosti oko osobnog usavršavanja (Žanko, 1938, 263).

Profesor duhovne teologije na Papinskom istočnom institutu u Rimu Irénée Hausherr SJ tvrdi da je glavno obilježje svetosti upravo to jedinstvo života, a u tome mu je »Ivan Merz ostavio dojam da ju je više nego itko ostvario u svome životu« (Hausherr).

Autentičnost nečije povezanosti s Bogom bolje se provjerava u svakodnevici negoli u molitvenim trenutcima, smatra njegova suvremenica te dodaje da su »u njemu gledale čovjeka, koji je s Bogom živio i s Bogom bio združen ne samo u zanosu ranih jutara i tihih večernjih adoracija, već uvijek i svagdje. Zato se u njegovoj blizini nije moglo misliti nešto nedolično i nevrijedno, jer je njegova prisutnost sve pročistila, sve produhovila« (Stanković, 1938, 290).

Njegovo sjedinjenje s Kristom po liturgiji, osobnoj molitvi, pobožnostima i askezi imalo je očito velike posljedice na njegov svakodnevni život, tako da je sama njegova svakodnevica postala bogo-služenje (LG 34).

Jedinstvo života redovito se dostiže davanjem primata kontemplativnoj dimenziji života. Merz se zdušno dao na promociju Katoličke akcije, koju je potaknuo Pio XI. s ciljem rekristijanizacije društva. Naglasak na društvenom i socijalnom aspektu i angažmanu često je jednostrano vodio prema politizaciji katoličanstva: »Katoličku omladinu poticalo se, doduše, preko katoličke štampe na rad, na vanjski aktivitet, na borbu s neprijateljima vjere, na organiziranje katoličkog fronta, ali riječ biskupa Mahnića o nutarnjoj pripravi za katolički rad pomalo se zaboravljala« (Stanković, 1938, 284). Zato je on uporno i odlučno inzistirao na »kontemplaciji kao bitnom preduvjetu akcije« (Žanko, 1938, 247).

\section{Zaključak}

Merz se upoznao i oduševio za liturgiju, osobito nakon obavljenih liturgijskih duhovnih vježbi koje je obavljao u Mödlingu kraj Beča dok je još bio ondje student (Merz, 2014, 386).

Usredotočio se osobito na euharistiju i liturgiju časova, a ostalim sakramentalnim organizmom nije se bavio. Premda je poznavao i literaturu ondašnjih teo- 
loga, ipak su njegov osnovni izvor dokumenti crkvenog učiteljstva, koje je zanosno iščitavao i druge u njih uvodio. Upravo ta činjenica omogućila mu je da ne upadne u jednostranosti, nego je uravnoteženo promovirao liturgijski život. Ivan nije idejno i sadržajno inovativan (tu se drži strogo učiteljstva), nego više u metodi: na koji način svjesno i aktivno sudjelovati u liturgijskom životu, da on uistinu postane izvor duhovnog života i vrhunac sve djelatnosti Crkve. On to predstavlja na jedan egzistencijalan način, ponajprije svojim primjerom, a potom i svojim poukama drugima koje su plod njegova iskustva.

Merz može biti model također po jednom integralnom pristupu liturgijskoj duhovnosti. On, naime, nikada ne promatra liturgiju izolirano iz cjelokupnog kršćanskog života. Za razliku od postridentske duhovnosti, on naglašava njezin primat, ali istodobno izbjegava izvjesni „panliturgizam“, koji isključuje meditaciju i izvanliturgijsku pobožnost. Jasno, doduše, ističe primat kontemplativne dimenzije njegovane u liturgiji i izvanliturgijskoj pobožnosti, ali se protivi da bi ona mogla biti svrha sebi samoj te izgubiti poveznicu sa svakodnevicom i apostolskim angažmanom. Prožetost tih triju stvarnosti bitno je obilježje liturgijske duhovnosti kako ju je on živio i promovirao.

Njegov integralni pristup ne odnosi se samo na kršćanski duhovni život, nego želi uključiti i druge dimenzije ljudskog života: umjetnost, arhitekturu, književnost, glazbu. U tom kontekstu valja promatrati i njegovu doktorsku disertaciju na temu utjecaja liturgije na književnost.

Može nam biti i model primata kontemplativne dimenzije, koja se u legitimnoj suvremenoj ideji „otvaranja svijetu“ spontano nerijetko zapostavila. Taj primat nipošto ne znači zanemarivanje angažmana, što bi bilo protivno ideji Katoličke akcije kao i stvarnomu Ivanovu životu, nego je riječ ponajprije o primatu poslušnosti Bogu i njegovu planu, da se bude na Božji način založen oko izgradnje boljeg društva. Tim primatom ujedno će se depolitizirati aktivnosti koje nose katolički predznak.

\section{Literatura}

AA. Apostolicam actuositatem. U: Drugi vatikanski koncil: Dokumenti. Zagreb: Kršćanska sadašnjost, 2008.

Benedikt XVI. (2013). Incontro con i parroci e il clero di Roma: Discorso del Santo Padre Benedetto XVI: Aula Paolo VI: Giovedì, 14 febbraio 2013. URL: http://www.vatican.va/holy_father/benedict_xvi/speeches/2013/february/documents/hf_ben-xvi_ spe_20130214_clero-roma_it.html (07.03.2013.)

Benigar, Aleksa (2014). Sveto evanđelje po Mateju: Duhovna razmatranja. Zagreb: Hrvatska franjevačka provincija sv. Ćirila i Metoda.

Castellano, Jesùs (2003). Teologia Spirituale. U: Giacomo Canobbio i Piero Coda (ur.), La Teologia del XX secolo: Un bilancio. Roma: Città Nuova.

EG. Evangelii gaudium. U: Franjo, Evangelii gaudium - Radost evanđelja: Apostolska pobudnica o naviještanju evanđelja u današnjem svijetu. Zagreb: Kršćanska sadašnjost, 2014.

Faggioli, Massimo (2015). Spiritualità liturgica e movimenti ecclesiali: da Giovanni Paolo II a Francesco. Rivista liturgica, 102, 4, 675-682. 
Gračanin, Đuro (1933). Moje uspomene na ličnost dr. Ivana Merza. Sarajevo: Nova Tiskara Vrčak. URL: http://ivanmerz.hr/staro/knjige_o/Gracanin/Moje_uspomene_na_Merza. htm (27.03.2017)

Häring, Bernard (1966). Il Concilio comincia adesso. Alba: Paoline.

Hausherr, Irénée. Hrvati ne bi smjeli dopustiti da umre spomen na Ivana Merza! U: Blaženi Ivan Merz. URL: http://ivanmerz.hr/staro/drugi_o/suvremenici/ (28.03.2017.)

Ivan Pavao II. (2003). Budućnost ovih krajeva ovisi i o vama! Propovijed Svetoga Oca na svetoj misi u Banjoj Luci prigodom proglašenja blaženim Ivana Merza. Vjesnik akovačke i Srijemske biskupije, 131, 7-8, 542.

IO. Inter Oecumenici. U: Enchiridion Vaticanum 2: Documenti ufficiali della Santa Sede: 1963-1967. Bologna: Dehoniane, 1979.

Jäger, Ivan (1938). Moj susret s Ivom... Život, 19, 5, 301-305.

LG. Lumen gentium. U: Drugi vatikanski koncil: Dokumenti. Zagreb: Kršćanska sadašnjost, 2008.

Luciani, Albino (1980). Il buon Samaritano: Corso di Esercizi spirituali. Padova: Messaggero.

Merz, Ivan, (1993). Put k suncu: Ivan Merz ti govori: Odabrani tekstovi iz dnevnika i ostalih spisa Sluge Božjega Ivana Merza: Priredio i komentirao o. Božidar Nagy. Zagreb: Filozofsko-teološki institut Družbe Isusove - Postulatura za beatifikaciju Ivana Merza.

Merz, Ivan (2011). Sabrana djela: Svezak 1: Književnost: Liturgija: Katolička akcija. Zagreb: Postulatura za kanonizaciju bl. Ivana Merza - Filozofski fakultet Družbe Isusove Glas Koncila.

Merz, Ivan (2014). Sabrana djela: Svezak 4: Dnevnik. Zagreb: Postulatura za kanonizaciju bl. Ivana Merza - Filozofski fakultet Družbe Isusove - Glas Koncila.

Nagy, Božidar (1971). Borac s bijelih planina: Ivan Merz. Zagreb: Filozofsko-teološki institut Družbe Isusove.

Nagy, Božidar (2005). Izvor života: Blaženi Ivan Merz i Euharistija. Zagreb: Postulatura za beatifikaciju bl. Ivana Merza.

Neunheuser, Bernhard (2001a). Spiritualità Liturgica. U: Domenico Sartore, Achille Maria Triacca i Carlo Cibien (ur.), Liturgia (str. 1915-1936). Cinisello Blasamo: San Paolo.

Neunheuser, Bernhard (2001b). Movimento liturgico. U: Domenico Sartore, Achille Maria Triacca i Carlo Cibien (ur.), Liturgia (str. 1915-1936). Cinisello Blasamo: San Paolo.

Prétot, Patrick (2013). Ivan Merz u liturgijskom pokretu: baštinik Dom Guérangera. U: Ivan Merz, Utjecaj liturgije na francuske pisce od Chateaubrianda do naših dana: 1700.-1923. (str. 379-387). Zagreb: Postulatura za kanonizaciju bl. Ivana Merza.

Pušić, Miho (1966). Izjava povodom 70 - godišnjice rođenja dr. Ivana Merza. Vjesnik akovačke biskupije, 19, 12, 227.

Ribić, Stjepan (2013). Umjetnost i estetika u pisanoj ostavštini Ivana Merza. Obnovljeni život, 68, 2, 151-164.

SAC. Sacramentum caritatis. U: Benedikt XVI., Sacramentum caritatis - Sakrament ljubavi: Postsinodalna apostolska pobudnica o euharistiji, izvoru i vrhuncu života i poslanje Crkve. Zagreb: Kršćanska sadašnjost, 2007.

SC. Sacrosanctum concilium. U: Drugi vatikanski koncil: Dokumenti. Zagreb: Kršćanska sadašnjost, 2008.

Stanković, Marica (1938). Merz — Božji čovjek svagdašnjice. Život, 19, 5, 283-293. 
Šeper, Franjo (1970). Moja sjećanja na dr. Ivana Merza. U: Blaženi Ivan Merz. URL: http:/ivanmerz.hr/staro/drugi_o/suvremenici/ (28.03.2017.)

Škarica, Marin (1997). Liturgijski život i djelovanje Ivana Merza. Obnovljeni život, 52, 3-4, 257-270.

Vauchez, André (2006). La spiritualità dell'Occidente medioevale. Milano: Vita e Pensiero.

Vrbanek, Josip (1943). Vitez Kristov: Dr Ivan Merz. Zagreb: Veliko križarsko bratstvo i Veliko križarsko sestrinstvo.

Žanko, Dušan (1938). Duša Dra Ivana Merza: Esej o 10-godišnjici smrti. Život, 19, 5, 245-273.

\section{The Liturgical Spirituality of Bl. Ivan Merz}

Franjo Podgorelec*, Ivan Crnkovic***

\section{Summary}

Today, experience is again valued in theology. In this respect, the need is stressed for truths and values, aside from abstract notions involving man's rational dimension, to be transmitted by way of a "model" which includes also the experiential-emotional dimension. Through the "model" method a particular truth and value is presented in the manner in which it is embodied and lived by a specific person, thus gaining in appeal. In this article, Ivan Merz is depicted as the model which existentially brought to pass the sustainable idea of a liturgical movement, of which he was an adherent, and also of a conciliar liturgical reform: to reestablish the liturgy as the source of spiritual life. In doing so, he skillfully avoids any one-sidedness and exclusivity. He stresses, and rightly so, the primacy of the liturgy, but without entering into a kind of „panliturgism“. Furthermore, he values extra-liturgical devotions, as well as individual prayer, but does not detach them from the liturgical context. Finally, he is aware that the liturgy must shape our mentality and activites in our daily lives and in society, however, by giving primacy to the contemplative dimension, he avoids allowing Christian involvement to be transformed into just another type of social program. Therefore, Merz is an example to us of an integral approach in which all three dimensions are intertwined, this not always being the case in ecclesial practice. The paper uses the analytical method to examine Merz's works, his experience and numerous testimonies about him. Some controversies over the liturgical spirituality of his time are presented through the historical-descriptive method.

Key words: liturgical spirituality, extra-liturgical devotions, Catholic Action, primacy of contemplation, liturgical movement, unity of life

* Senior Assistant Franjo Podgorelec, Ph.D., Catholic Faculty of Theology, University of Zagreb. Address: Vlaška 38, 10000 Zagreb, Croatia. E-mail: franjo.podgorelec@gmail.com

** Ivan Crnković, OFM, B.Th., Catholic Faculty of Theology, University of Zagreb. Address: Vlaška 38, 10000 Zagreb, Croatia. E-mail: ivan.crnkovic11@gmail.com 